\title{
REDESIGNING THE ASSIGNMENT OF INTERNAL AUDITORS BASED ON AUDITOR UTILITY
}

\author{
Burcu KARAÖZ ${ }^{1}$
}

Received Date (Başvuru Tarihi): 14.06.2016

Accepted Date (Kabul Tarihi): 04.09.2016

\begin{abstract}
This paper introduces a novel model for assignment of internal auditors to branches of businesses. Numerous internal auditor assignment studies proposed models that minimized the cost. The primary interest of this paper focuses on maximizing auditor's utility. The main idea is that Each branch has different impact values for auditors, which indicate auditors' utility level in terms of location, size and type of branches. Therefore, an integer programming model formulated. Equivalence of auditor's working days and total gained impact values are constraints for the proposed model. This paper is threefold. First, quantification of the branches' effects on the auditors. AHP method is used to define branches' impact values. Second, simulating the durations of auditing process to minimize the effect of abnormal situations. Third, solving proposed model for routing the internal auditors and designating the total working days and the total utility score of the auditor.
\end{abstract}

Key Words: Internal Auditor, Routing, Utility Maximization

Jel Codes: C610, M420, M490

\section{İÇ DENETÇİ ATAMALARININ DENETÇİ FAYDASI TEMELINDE YENIDEN TASARLANMASI}

\section{ÖZ}

Çalışmada iç denetçi atama modellerine yeni bir yaklaşım önerilmektedir. Geçmişte yapılmış iç denetçi atama çalışmaları genellikle maliyet minimizasyonu üzerine kurulmuştur. Bunlardan farklı olarak ilgili çalışmanın çıkış noktası ise iç denetçilerin faydalarını maksimize etmektir. Her şubenin konumu, şube büyüklüğü, şube tipi gibi özellikleri dolayısıyla denetçiler için farklı fayda değelerine sahip olduğu fikrinden yola çıkılmıştır. Bu doğrultuda her şube için fayda değerleri belirlenmiş ve iç denetçilerin atanmasında bu faydanın en büyüklenmesinin amaçlandığı bir tam sayıl programlama modeli kurulmuştur. Ilgili matetiksel modelin kısıtları, denetçilerin gidecekleri şubelerden elde edecekleri fayda değerlerinin birbirine yakın olması, tüm denetçilerin çalışma günlerinin birbirine yakın olması ve toplam fayda değerlerinin birbirine yakın olmasıdır. Çalışma üç aşamalıdır. Birinci aşama Analitik hiyerarşi prosesi yöntemi ile şubelerin fayda değerleri elde edilmesidir. İkinci aşama simulasyon yöntemi ile her şube için denetim işinin yaklaşık süresi belirlenmesidir. Son aşama ise iç denetçilerin çalışma güzergahlarının belirlenmesi ve toplam çalışma günleri ve toplam fayda bilgilerinin elde edilmesi için matematiksel modelin çözdürülmesidir.

Anahtar Kelimeler: İç Denetçi, Güzergah Belirleme, Fayda Maksimizasyonu

Jel Kodları: C610, M420, M490

\footnotetext{
${ }^{1}$ Araş. Gör., Yaşar Üniversitesi, İşletme Fakültesi, İşletme Bölümü, burcu.karaoz@yasar.edu.tr
} 


\section{Introduction}

Most of the large sized companies need to consult the activities to add value and improve the efficiency of organization's operations. Chiefly, the companies that has branches, require internal auditor teams. Electronic retailers, supermarket chains or banks could be stated as examples. The assignment procedure of auditors to branches comprises several complexities. Total number of branches and average audit durations are main subjects of planning audit schedule. In this study auditing costs of the branches are accepted as independent from the auditors. Costs are dependent to duration of audit program. Therefore, the total cost is assumed as it remains stable. Also branches are categorized according to two features, the location of branches (in same city with the headquarters or not) and size of branches (retail, corporate, commercial and private banking etc.). In addition, utility maximization is purposed for this assignment problem, instead of cost minimization. Because motivation of auditors could have a positive impact on quality of audit process and duration of audit program. Utility means that each branch can have different impact values for the auditors. Those impact values correlate with specific criterions like location, size and type of branches. As the primary interest of this paper, to maximize the utility of auditors, firstly the impact values of branches are designated, secondly durations of auditing are simulated and correlatively cost of auditing for branches, finally integer programming model with using simulated data is solved and worktable for auditors is constructed.

\section{Literature Review}

Assignment problems are considering with assigning $\mathrm{n}$ item (job, branch) with $\mathrm{m}$ item (machine, auditor). As an optimization problem, aim is making the best assignment with respect to the constraints. After 1950, assignment problems are discussed by Neumann (1953), Kuhn (1955), Ford and Fulkerson (1956), Montzkin (1956), Monkers (1957).

Staff scheduling or rostering problems were introduced by Dantzig and Edie in 1950s. The aim is preparing a work timetable and assigning staff to jobs to satisfy organizations demand. In the lights of Edie and Dantzig, lots of researchers developed staff scheduling algorithms. Also those methods have been used for transformation and assignment problems.

As a special type of assignment and staff scheduling problems, auditing staff assignment problems were started to tackle in early 70s. Edward L. Summer in 1972 worked on conforming with the limitations of an audit office and meeting the objectives of that office, 
to audit engagements by assigning the audit staff. In Summer's study linear programming model was described for assignment problem. The aim was maximizing the audit office's professional and economic objectives. He also reached some useful information about fair and reasonable staff compensation policy, the additional work which be sought from clients, encouragement of staff for working additional hours, schedule of professional development and education.

In 1974 Bailey, Boe and Schnack published a paper and they develop two objections for Summer's study. Their argument was using goal programming instead of linear programming is more useful on audit staff assignment. Because, while using linear programming one objective function can be optimized and it must be composite function but in the audit staff assignment problem maximizing or minimizing several objective functions can be used. On this point of view, they adjusted Summer's model as goal programming and resolved. The results showed that goal programming provides an obvious improvement for audit staff assignment problems via linear optimizing models.

Blocher (1979) made a study which examines the effect of different assignment strategies on audit staff performance. The intent was determining the relationship between assignment policy and the performance of audit seniors.

In early 1980s, Balachandran and Zoltners (1981) designed an integer programming model to assign audit staff to audit engagements in the most effective way. Objective of the study was minimization of total cost. Also in 1982 Balachandran and Steuer published another paper about CPA firm's audit staff planning problem with multiple objectives. The results proposed recommendations about allocating the projected workload among the auditors and altering the staff level.

Chan and Dodin (1986) extended the integer programming model which is presented by Balachandran and Zoltners (1981). Due dates, precedence constraint, penalty cost, resource levelling are added to old model. They used versatile computer model and it helped to be flexible while implementing the model thus improved the realism of the scheduling model. In 1991 Chan and Dodin enhanced their study and described the methods to solve such a complex problem and applied these methods to real life audit schedule case. Also Dodin (1999) asserted that through efficient scheduling audit firms can determine the load and schedule of every auditor, over time requirements, travel schedules and costs, and can respond 
to changes in the information set (input data) easily. Therefore, proposed a model that used project management as assigning tool.

Chang (2002) introduced an approach to resolving audit staff scheduling for multiple and large engagements. The major advantage of the proposed method is solving staff resource allocation problems by alleviating the limitations of both linear and integer programming. Abdioglu (2008) and Kır (2010), asserted risk based auditor assignment. Chen et. Al. (2012) investigated a model that aimed to assign auditors due to improving audit quality. They stated a genetic algorithm and optimally assigned auditors and the manager responsible for assignment.

\section{Model Description}

Previous studies are usually about external audit staff assignment and scheduling problems; therefore, internal audit staff who are controlling branches that are parts of the same corporation are addressed in this paper. Both to solve internal auditor assignment problem and to schedule work timetable of auditors, integer programming model is designated. Objective is maximizing auditors' utility, under time and budget equality constraints. Model's objective function is;

Maximize $\mathrm{Z}=\sum_{i}^{n} \sum_{j}^{t} f_{i} * x_{i j}$

Constraints;

$\sum_{i}^{n} \sum_{j}^{t} d_{i} * x_{i j}=1$

$\sum_{i}^{n} d_{i} * x_{i j}-\sum_{i}^{n} d_{i} * x_{i(j+1)}<=\mathrm{a} \quad$ for all $\mathrm{j}$ in $\mathrm{t}$

$\sum_{i}^{n} d_{i} * x_{i j}-\sum_{i}^{n} d_{i} * x_{i(j+1)}>=-\mathrm{a} \quad$ for all $\mathrm{j}$ in $\mathrm{t}$

$\sum_{i}^{n} f_{i} * x_{i j}-\sum_{i}^{n} f_{i} * x_{i(j+1)}<=\mathrm{b} \quad$ for all $\mathrm{j}$ in $\mathrm{t}$

$\sum_{i}^{n} f_{i} * x_{i j}-\sum_{i}^{n} f_{i} * x_{i(j+1)}>=-\mathrm{b} \quad$ for all $\mathrm{j}$ in $\mathrm{t}$

$x_{i j}=0$ or 1 (binary)

i : branch 
j : auditor

$\mathrm{n}$ :number of branches

$\mathrm{t}$ : number of auditors

$\mathrm{x}$ : 0 if auditor $\mathrm{j}$ does not go to branch $\mathrm{i}, 1$ if auditor $\mathrm{j}$ goes to branch $\mathrm{i}$.

$\mathrm{f}$ : impact value for each branch

d : duration of audit

a : difference between total working days of each auditors

b : difference between total impact values of each auditors

Equation (1) is objective function and it aims to maximize the impact value of branches on the auditors. Equation (2) assigns exactly one auditor to each branch. In equation (3) and (4) difference between auditors' total working days are balanced with +- 5 days. With the same purpose, equation (5) and (6) means that difference in total impact values of each auditor can be maximum 5 and minimum -5. Equation (7) states that all decision variables are binary so this model is an integer programming model.

This model helps to maximize and also balance auditor's total impact values while assigning the auditors to branches. After the model is launched, results as auditor $\mathrm{x}$ should go branch a and branch b etc. will be obtained. Also the costs of each branch, total working days of each auditor, total utility scores of each auditor and how much money the auditor will need are appeared.

\section{Implementation}

This model is implemented to an internal auditing department of a Turkish banking corporation which's headquarter is in Istanbul. In this bank, there are three different types of branches and total numbers of branches are 80. Also the department has 5 internal auditors to control those branches. 65 of those branches are in Istanbul and 15 of the branches are in the different cities. This department is not using an assignment method; the manager is making monthly schedule for the auditors. Preparing a long run work schedule and disburdening the manager who are making the program are aimed in this study. 
Firstly, the features of branches which are mostly important for auditors are amassed, to use in AHP as decision criteria. Analytic hierarchy process (AHP) firstly discussed by Thomas Saaty in 1977. This method provides a tool to make decisions in situations involving multiple objectives (Winston, 1994). In this study to reach a powerful impact value for each branch, decision criterions are defined and evaluated for each branches. location of branch (like near the hotel or restaurant), size of branch and type of branch are mentioned criterions. From the auditors received opinions about each branches and each criterion to use in AHP. Criterions and weights can be shown in Table 1.

Table 1: AHP Criterions and Weights

\begin{tabular}{|l|c|c|r|r|}
\hline \multicolumn{1}{|c|}{ Criterions } & Location Of Branch & Size Of Branch & Type Of Branch & Weights \\
\hline Location Of Branch & 1,00 & 5,00 & 3,00 & 0,633 \\
\hline Size Of Branch & 0,20 & 1,00 & 0,33 & 0,106 \\
\hline Type Of Branch & 0,33 & 3,00 & 1,00 & 0,260 \\
\hline
\end{tabular}

According to those three criterions, impact values of each branch which is evaluated by AHP method are shown in Table 2 .

After the impact values are determined, the duration of audit process for each branches are simulated. Branches are categorized as corporate, commercial and private banking. The duration of auditing is depending on the type of branch. Duration of auditing for branches is not stabile, an uncertainty is existing. To reduce the effect of this uncertainty, triangular distribution is used while simulating the duration of auditing for branches. The detailed information about the durations is shown in Table 3. According to pessimistic, optimistic and possible durations of each type the simulation is run, 1000 different numbers are generated and then averaged for each branch. Simulated duration constitutes one of the constraints of integer programming model. 
Table 2: Impact Values of Branches

\begin{tabular}{|c|c|c|c|c|c|c|c|c|c|c|c|c|c|c|c|}
\hline 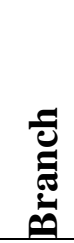 & 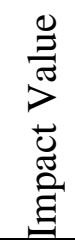 & ปี & 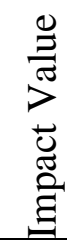 & صี & 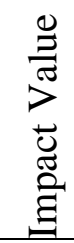 & 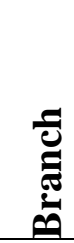 & 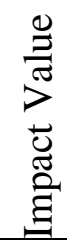 & 롤 & 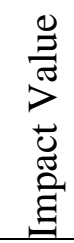 & 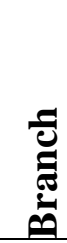 & 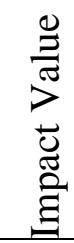 & 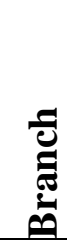 & 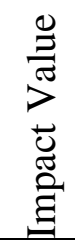 & 氖 & 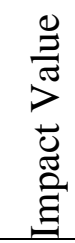 \\
\hline 1 & 35 & 11 & 26 & 21 & 19 & 31 & 14 & 41 & 10 & 51 & 8 & 61 & 6 & 71 & 3 \\
\hline 2 & 32 & 12 & 22 & 22 & 19 & 32 & 13 & 42 & 10 & 52 & 7 & 62 & 6 & 72 & 4 \\
\hline 3 & 26 & 13 & 23 & 23 & 18 & 33 & 12 & 43 & 10 & 53 & 8 & 63 & 5 & 73 & 3 \\
\hline 4 & 29 & 14 & 19 & 24 & 18 & 34 & 12 & 44 & 10 & 54 & 7 & 64 & 5 & 74 & 3 \\
\hline 5 & 31 & 15 & 22 & 25 & 16 & 35 & 12 & 45 & 8 & 55 & 7 & 65 & 5 & 75 & 3 \\
\hline 6 & 24 & 16 & 19 & 26 & 15 & 36 & 13 & 46 & 9 & 56 & 7 & 66 & 4 & 76 & 3 \\
\hline 7 & 24 & 17 & 19 & 27 & 16 & 37 & 12 & 47 & 9 & 57 & 6 & 67 & 4 & 77 & 3 \\
\hline 8 & 27 & 18 & 18 & 28 & 15 & 38 & 12 & 48 & 9 & 58 & 6 & 68 & 5 & 78 & 4 \\
\hline 9 & 25 & 19 & 19 & 29 & 13 & 39 & 12 & 49 & 7 & 59 & 6 & 69 & 4 & 79 & 4 \\
\hline 10 & 23 & 20 & 17 & 30 & 13 & 40 & 11 & 50 & 8 & 60 & 6 & 70 & 4 & 80 & 3 \\
\hline
\end{tabular}

Table 3: Pessimistic, Optimistic and Possible Durations of Each Type of Branches

\begin{tabular}{|c|c|c|c|}
\hline & \multicolumn{3}{|c|}{ Duration } \\
\cline { 2 - 4 } & Corporate & Commercial & Private \\
\hline Optimistic & 8 & 6 & 4 \\
\hline Possible & 10 & 7 & 5 \\
\hline Pessimistic & 12 & 8 & 6 \\
\hline
\end{tabular}

Another important issue for the problem is cost and it depends on durations. If the branch is not in Istanbul, auditor will have 400TL for return flight ticket, 120 TL for shuttle, 150TL for hotel per night and also daily extra 100TL will be paid to auditor. If the branch is in Istanbul only extra $80 \mathrm{TL}$ will be paid. The cost is assumed as independent from the person. If this is a bounden duty like controlling the branches, the company will face this cost in any case, there will be no change in cost if person A goes to branch $\mathrm{X}$ instead of person $\mathrm{B}$. This means, costs won't be used in objective function or constraints. 
The model is solved in twofold, first for the branches which are not in Istanbul, second for the branches which are in Istanbul. The meaning of this is balancing the total duration of working in different cities for each auditor.

\section{Results}

Python-Gurobi Optimizer is used to solve the integer programming model in proposed study. Model assigned the auditors to branches within maximizing their total impact value for a year. Answers of questions such as; "which auditor will go to which branch and how much money he/she will need, how many days will the auditing take and what is the impact value he/she gain?” appear in results. Output of our model for branches which are not in Istanbul is summarized in Table 4 and the output for the branches which are in Istanbul is summarized in Table 5.

Table 4: Results of The Solution For Branches Which Are Not in Istanbul

\begin{tabular}{|c|c|c|c|c|c|c|c|c|c|c|c|c|c|c|}
\hline 总 & 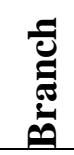 & 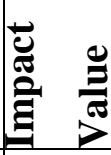 & 总 & 氙 & 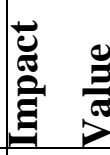 & 总 & 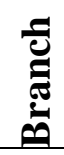 & $\begin{array}{l}\overrightarrow{\tilde{Z}} \\
\text { 家 } \\
\end{array}$ & 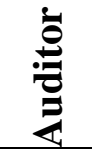 & 氙 & 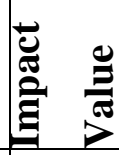 & 苞 & 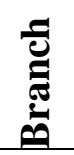 & 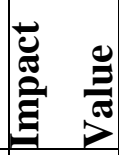 \\
\hline 1 & 6 & 24 & 2 & 2 & 32 & 3 & 1 & 35 & 4 & 4 & 29 & 5 & 3 & 26 \\
\hline 1 & 8 & 27 & 2 & 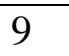 & 25 & 3 & 13 & 23 & 4 & 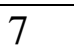 & 24 & 5 & 5 & 31 \\
\hline 1 & 11 & 26 & 2 & 10 & 23 & 3 & 15 & 22 & 4 & 12 & 22 & 5 & 14 & 19 \\
\hline
\end{tabular}


Table 5: Results of The Solution For Branches Which Are in Istanbul

\begin{tabular}{|c|c|c|c|c|c|c|c|c|c|c|c|c|c|c|c|c|c|c|}
\hline 苞 & 돌 & 鴶 & $\begin{array}{l}\frac{9}{\pi} \\
\frac{\pi}{\nu}\end{array}$ & 苞 & 氙 & 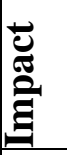 & 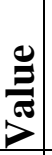 & 总 & 氙 & 苂 & $\begin{array}{l}\frac{0}{\Xi} \\
\frac{\partial}{\nu}\end{array}$ & 苞 & ฮี & 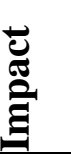 & $\begin{array}{l}\frac{0}{3} \\
\frac{\pi}{2}\end{array}$ & 总 & 氖 & 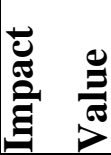 \\
\hline 1 & 24 & 18 & & 2 & 19 & 19 & & 3 & 16 & 19 & & 4 & 18 & 18 & & 5 & 23 & 18 \\
\hline 1 & 26 & 15 & & 2 & 20 & 17 & & 3 & 17 & 19 & & 4 & 22 & 19 & & 5 & 33 & 12 \\
\hline 1 & 31 & 14 & & 2 & 25 & 16 & & 3 & 21 & 19 & & 4 & 28 & 15 & & 5 & 36 & 13 \\
\hline 1 & 34 & 12 & & 2 & 27 & 16 & & 3 & 32 & 13 & & 4 & 30 & 13 & & 5 & 38 & 12 \\
\hline 1 & 39 & 12 & & 2 & 29 & 13 & & 3 & 35 & 12 & & 4 & 37 & 12 & & 5 & 42 & 10 \\
\hline 1 & 43 & 10 & & 2 & 47 & 9 & & 3 & 41 & 10 & & 4 & 40 & 11 & & 5 & 44 & 10 \\
\hline 1 & 46 & 9 & & 2 & 49 & 7 & & 3 & 48 & 9 & & 4 & 51 & 8 & & 5 & 45 & 8 \\
\hline 1 & 54 & 7 & & 2 & 56 & 7 & & 3 & 57 & 6 & & 4 & 53 & 8 & & 5 & 50 & 8 \\
\hline 1 & 55 & 7 & & 2 & 58 & 6 & & 3 & 60 & 6 & & 4 & 61 & 6 & & 5 & 52 & 7 \\
\hline 1 & 63 & 5 & & 2 & 59 & 6 & & 3 & 66 & 4 & & 4 & 62 & 6 & & 5 & 65 & 5 \\
\hline 1 & 69 & 4 & & 2 & 64 & 5 & & 3 & 71 & 3 & & 4 & 67 & 4 & & 5 & 68 & 5 \\
\hline 1 & 70 & 4 & & 2 & 77 & 3 & & 3 & 76 & 3 & & 4 & 79 & 4 & & 5 & 72 & 4 \\
\hline 1 & 75 & 3 & & & & & & & & & & & & & & 5 & 73 & 3 \\
\hline \multirow[t]{2}{*}{1} & 78 & 4 & & & & & & & & & & & & & & 5 & 74 & 3 \\
\hline & & & & & & & & & & & & & & & & 5 & 80 & 3 \\
\hline
\end{tabular}

The auditors' total auditing days, total cost of all auditing process and total amount of gained impact values in a year are clarifying in Table 6, Table 7 and Table 8 . In first table total utility scores implies summation of auditor's gained impact values which are gained from branches in Istanbul or from out of Istanbul. This means, for next year, in total, Auditor 1's gained impact value will be 201, Auditor 2's gained impact value will be 204, Auditor 3's gained impact value will be 203, Auditor 4's gained impact value will be 199 and Auditor 5's gained impact value will be 197. The auditors assigned to the branches levelly. Total amount of gained utility or impact values for all auditors are close. 
Table 6: Results About Total Utility Scores

\begin{tabular}{|c|c|c|c|c|c|}
\hline Utility & Auditor 1 & Auditor 2 & Auditor 3 & Auditor 4 & Auditor 5 \\
\hline In Istanbul & 124 & 124 & 123 & 124 & 121 \\
\hline Not in Istanbul & 77 & 80 & 80 & 75 & 76 \\
\hline Total Utility Score & 201 & 204 & 203 & 199 & 197 \\
\hline
\end{tabular}

Other inherences from the results are summarized in Table 7 and Table 8 . Table 7 indicates that Auditor 1 will need totally 13.470 TL for next year, Auditor 2 will need totally 13.060 TL for next year, Auditor 3 will need totally 13.900 TL for next year, Auditor 4 will need totally 13.870 TL for next year and Auditor 5 will need totally 14.410 TL for next year. This information helps to the company, while budgeting auditing department. Table 8 shows us total amount of days which an auditor will be outside of the headquarters for controlling the branches. According to those values work scheduling for each auditor can be done. This model and solution provides flexibility to both auditor and manager. There are two options for scheduling the auditing process. First one is just informing the auditor about the branches that he/she must go the next year and the auditor organizes his/her own working schedule. Second option is organizing the auditors' work schedule by manager according to results of the model.

Table 7: Inferences About Cost

\begin{tabular}{|c|c|c|c|c|c|}
\hline Cost & Auditor 1 & Auditor 2 & Auditor 3 & Auditor 4 & Auditor 5 \\
\hline In Istanbul & $7.360,00 \mathrm{TL}$ & $7.200,00 \mathrm{TL}$ & $7.040,00 \mathrm{TL}$ & $6.960,00 \mathrm{TL}$ & $7.200,00 \mathrm{TL}$ \\
\hline Not in Istanbul & $6.110,00 \mathrm{TL}$ & $5.860,00 \mathrm{TL}$ & $6.860,00 \mathrm{TL}$ & $6.910,00 \mathrm{TL}$ & $7.210,00 \mathrm{TL}$ \\
\hline Total Cost & $13.470,00 \mathrm{TL}$ & $13.060,00 \mathrm{TL}$ & $13.900,00 \mathrm{TL}$ & $13.870,00 \mathrm{TL}$ & $14.410,00 \mathrm{TL}$ \\
\hline
\end{tabular}

Table 8: Inferences About Durations

\begin{tabular}{|c|c|c|c|c|c|}
\hline Duration of Auditing & Auditor 1 & Auditor 2 & Auditor 3 & Auditor 4 & Auditor 5 \\
\hline In Istanbul & 92 & 90 & 88 & 87 & 90 \\
\hline Not in Istanbul & 17 & 16 & 20 & 19 & 19 \\
\hline Total Duration of Auditing & 109 & 106 & 108 & 106 & 109 \\
\hline
\end{tabular}




\section{Conclusion}

Assignment problems are common and have flexible solutions Proposed paper introduced an application of assignment problem for internal auditing staff. In order to assign auditors to branches, maximizing the auditors' total utility is used. Previous studies are implemented in auditing companies and utility of auditors was not the major objective so proposed model is a novel approach for assignment of auditing staff. Also paper enables adapting the model to different companies which have branches and need to audit them in a given period of time.

As mentioned above in this approach an integer programming model is introduced. The objective of model is maximizing the employee's total utility score which is consisted of summation of the impact values of each branch that he/she will control. The starting points of this objective are;

- The cost of controlling for all branches is assumed fixed; it does not change according to auditors. Therefore cost minimization is not a requirement for assignment..

- Some of branches can be unpreferable or less preferable. So while assigning the workers to branches manager should be fair while assigning to keep his/her team motivated.

For the implementation, Internal Auditing Department of a Turkish Bank is selected. There are five different auditors in the department and they are in charge of controlling of 80 branches. As preparation of the mathematical model, firstly the impact values of branches is defined with AHP method and then the duration of auditing process is simulated. After all data is prepared to use in the integer programming model, Python-Gurobi Optimizer is run to solve the model. The solution process takes approximately 1 minute, then total gained impact values of auditors is maximized and the auditors are assigned to branches. While maximizing and assigning, equivalence of auditors' total working days and total gained impact values are constrained the model. The results indicates that total gained impact value of all auditors will be 1004 and personal gained impact values will be balanced if Auditor 1 goes to the branches 24, 26, 31, 34, 39, 43, 46, 54, 55, 63, 69, 70, 75, 78, 6, 8, 11 and Auditor 2 goes to the branches 19, 20, 25, 27, 29, 47, 49, 56, 58, 59, 64, 77, 2, 9,10 and Auditor 3 goes to the branches 16, 17, 21, 32, 35, 41, 48, 57, 60, 66, 71, 76, 1, 13, 15 and Auditor 4 goes to the 
branches 18, 22, 28, 30, 37, 40, 51, 53, 61, 62, 67, 79,4, 7, 12 and Auditor 5 goes to the branches 23, 33, 36, 38, 42, 44, 45, 50, 52, 65,68, 72, 73, 74, 80, 3, 5, 14. 


\section{References}

Abdioğlu, H. (2008). Bölgesel Kalkınma Ajansları: Muhasebe İşlemleri ve Denetimi. I. Güney Marmara Bölgesel Gelişme Sorunları Sempozyumu, Bandırma-Balıkesir.

Bailey, A. D., Boe, W. J., \& Schnack, T., 1974. The audit staff assignment problem: a comment. Accounting Review, pp. 572-574.

Balachandran, K. R., \& Steuer, R. E. , 1982. An interactive model for the CPA firm audit staff planning problem with multiple objectives. Accounting Review, pp: 125-140.

Balachandran, B. V., \& Zoltners, A. A., 1981. An interactive audit-staff scheduling decision support system. Accounting Review, pp: 801-812.

Blocher, E., 1979. Performance effects of different audit staff assignment strategies. Accounting Review, pp: 563-573.

Brody, R. G., \& Lowe, D. J., 2000.The new role of the internal auditor: implications for internal auditor objectivity. International Journal of Auditing,4(2), pp: 169-176.

Burkard, R. E. 2002. Selected topics on assignment problems. Discrete Applied Mathematics, 123(1),pp: 257302.

Chan, K. H., \& Dodin, B., 1986. A decision support system for audit-staff scheduling with precedence constraints and due dates. Accounting Review, pp: 726-734.

Chang, C. J. (2002). A decision support system for audit staff scheduling of multiple and large-scaled engagements. Review of Business Information Systems (RBIS), 6(1), 27-40.

Chen, R. C., Huang, C. C., \& Suen, S. P. (2012). On the Optimization of Auditor Assignment. In Information and Business Intelligence (pp. 617-622). Springer Berlin Heidelberg.

Dantzig, G. B., 1954. Letter to the Editor-A Comment on Edie's “Traffic Delays at Toll Booths”. Operations Research, 2, pp: 339-341.

Dodin, B., \& Huang Chan, K., 1991. Application of production scheduling methods to external and internal audit scheduling. European Journal of Operational Research, 52(3),pp:267-279.

Dodin, B. (1999). Project Management in Audit Staff Scheduling. In Project Scheduling (pp. 509-527). Springer US.

Edie, L. C., 1954.Traffic Delays at Toll Booths. Operations Research, 2,pp:107-138

Ernst, A. T., Jiang, H., Krishnamoorthy, M., \& Sier, D., 2004. Staff scheduling and rostering: A review of applications, methods and models. European journal of operational research, 153(1),pp:3-27.

Ford Jr, L. R., \& Fulkerson, D. R., 1956.Solving the transportation problem.Management Science, 3(1),pp: 2432.

Fowler, J. W., Wirojanagud, P., \& Gel, E. S., 2008. Heuristics for workforce planning with worker differences. European Journal of Operational Research,190(3),pp: 724-740.

Kir, H. (2010). Stratejik Denetim ve Denetimde Risk Odaklılık. Denetişim Dergisi, 4, 47-62.

Kuhn, H. W., 1955. The Hungarian method for the assignment problem. Naval research logistics quarterly, 2(12),pp: 83-97.

Munkres, J., 1957. Algorithms for the assignment and transportation problems.Journal of the Society for Industrial \& Applied Mathematics, 5(1), pp:32-38. 
Motzkin, T. S., 1956. The Assignment Problem1. Numerical analysis, (6), pp: 109.

Van den Bergh, J., Beliën, J., De Bruecker, P., Demeulemeester, E., \& De Boeck, L., 2013. Personnel scheduling: A literature review. European Journal of Operational Research, 226(3), pp: 367-385.

Saaty, T. L., 1977. A scaling method for priorities in hierarchical structures.Journal of mathematical psychology, 15(3),: 234-281.

Summers, E. L., 1972. The audit staff assignment problem: a linear programming analysis. Accounting Review, pp: 443-453.

Von Neumann, J., 1953. A certain zero-sum two-person game equivalent to the optimal assignment problem. Contributions to the Theory of Games, 2, pp: 5-12.

Winston, W. L., \& Goldberg, J. B., 1994.Operations research: applications and algorithms. 